\section{Gorbachev rails at Siberian science and "asset strippers"}

\section{London}

FHE "scientific approach" to the development of the Soviet Union's remoter regions came in for a drubbing from $\mathrm{Mr}$ Mikhail Gorbachev during his visit last week to Krasnoyarsk, the Siberian city at the centre of a region rich in unexploited mineral and natural resources.

Speaking to an audience of scientists, economic planners, agricultural managers and workers, he condemned past policies which, in the name of creating "building sites of communism", had meant that "both nature is under threat and man's interests find themselves somewhere down the line at the lowest levels".

Among those responsible for this situation he singled out Academician Gurii Marchuk, President of the Soviet Academy of Sciences, who, when head of the Siberian branch of the Academy had "failed to speak out and take a firm stance". A scientist's duty in such circumstances is, said to $\mathrm{Mr}$ Gorbachev, to "stand up straight and intervene at any state level, if what is necessary is not done".

The Krasnoyarsk krai (territory) is potentially one of the richest areas of the Soviet Union, possessing 50 per cent of Soviet coal reserves, 20 per cent of timber and hydroelectric resources, and a burgeoning non-ferrous metallurgical industry. No other region receives more capital investment, and the territory possesses academies, territorial production comp- lexes and a planning department.

"One would think that a reasonable approach could be organized on that basis", Mr Gorbachev observed. Instead, plans for the development of the territory had gone badly wrong, production facilities had been built without housing or a service infrastructure, and hydroelectric plants supposed to provide the power base for development had caused considerable environmental damage.

Mr Gorbachev said that managers and adminstrators had behaved more like asset-stripping colonizers than developers concerned with the long-term potential of the country. Some hydro-plants had been built too cheaply, while the endemic Soviet failing of "gigantomania" had led the planners to support huge hydroelectric complexes, like those at Krasnoyarsk and Sayan-Shushenskoe, without asking whether smaller stations, sited in accordance with the natural courses of the rivers, would have served better.

Publicly chastising the failings of one region or sector as a timely warning to the country as a whole is a traditional Soviet method of launching a new policy drive. But Mr Gorbachev's speech to the Krasnoyarsk scientists seems particularly apposite. What seems to have moved $\mathrm{Mr}$ Gorbachev to his stern speech is, first and foremost. the mood of the workers, who are losing patience with the "scientific solutions" offered.

\title{
Congress puts hot waste plans on ice
}

\section{Washington}

THE opening of the first permanent storage site for nuclear waste in the United States has been indefinitely delayed following a congressional hearing which, last week, revealed numerous doubts about the safety of the planned facility. The Waste Isolation Pilot Plant (WIPP) would have been one of the world's first purposebuilt geological repositories.

Seven hundred million dollars have already been spent at the WIPP site in Carlsbad, New Mexico, where a twothousand foot deep network of tunnels and chambers has been excavated in thick salt deposits. WIPP was due to begin receiving nuclear wastes from weapons production plants in October. Included for permanent storage would have been transuranic waste material contaminated with plutonium, whereas the Carlsbad plant was not intended to store high-level waste still generating heat.

WIPP has been plagued with problems ever since the New Mexico desert was selected for waste disposal in the early 1970s. Although the site had been selected for the stability and dryness of the salt deposits, chamber walls started to crack and creep and weep brine when the project was well underway, raising the prospect that barrels of waste might be crushed or corroded.

At last week's hearing the situation became even more complex when it emerged that some of the wastes are mixed with industrial solvents that could not be safely stored underground. Undocumented changes in design made it difficult to assess the overall safety of the facility and its capacity to resist earthquakes and fires. And legal disagreements between the federal government and the New Mexico government have left it unclear who has the final responsibility for licensing the plant.

The Department of Energy now says that WIPP will not begin receiving waste until scientists, Congress and the public are safisfied it is safe. The department cannot say how long that will take.

Alun Anderson
Student influx hits German universities

\section{Munich}

THE number of students crowding West German universities has once again increased, catching policy-makers by surprise. For years, politicians have been predicting a big fall in the number of new students. Instead, the latest figures, released last month by the West German Federal Statistics Office, show an 11.1 per cent increase at universities and other institutes of higher learning for the 1987-88 academic year.

The number of new students fell slightly in 1984 and 1985, encouraging finance ministers in the Länder (states) to sharpen the budget axe. (West German universities are funded primarily by the Länder.) But a few experts, such as the West German Rectors' Conference, warned that this was wishful thinking. The latest figures bear them out. The total number of students is close to $1,355,000$, near the peak of 1983-84. The universities are now operating at about 150 per cent of capacity. The increasing length of courses of study in both humanities and natural sciences implies that the universities will be packed well into the 1990s (see Nature 333, 198; and 333, 792; 1988).

Education ministry officials in several Länder have outlined measures designed to relieve overburdened professors and facilities. In Bavaria, the proposed twoyear university budget for 1989-90 includes expansion in several areas, but a spokesman admitted that the expansion targets set earlier in this decade foresaw a smaller number of students. Some universities, such as the University of Munich, which already has 62,000 students, simply cannot expand any further.

In Lower Saxony, spokesman Arpad Bogya said that special funds will be made available to universities to help them through this difficult period, but the amount - several million Deutschmarks — is too small to be of significant help.

The ministry officials explained the perplexing figures in terms of two phenomena: that university studies are becoming more popular among school leavers, and that people who have completed military service or practical training courses in preparation for entering careers have then opted for university studies as well. But most expect a sharp drop in the number of new students in two or three years at the latest. A spokeswoman in the Science Ministry in North RhineWestphalia explained that the number of 6-year olds beginning school there had dropped by half between 1970 and 1985 . 